\title{
Reformulasi Corigens dalam Sediaan Antiaging dan Joint Support Drink Mix Collagen Rousselot's
}

Lisa Marlina, Anggun Hari Kusumawati*, Lia Fikayuniar, Fitri Amalia, Nopita Aliani, Irma Rahmawati

Program Studi Farmasi, Fakultas Farmasi, Universitas Buana Perjuangan Karawang,

Jawa Barat, Indonesia

*Email: anggunhari@ubpkarawang.ac.id

(Submit 19/12/2021, Revisi 20/12/2021, Diterima 30/12/2021, Terbit 31/12/2021)

\begin{abstract}
Abstrak
Penurunan regeneratif sendi yang terjadi pada lanjut usia. Penggunaan Peptanß sebagai collagen peptida dengan profil asam amino yang unik mampu memperbaiki persendian dengan kekurangan mempunyai bau dan rasa yang tidak enak untuk dikonsumsi, sehingga perlu dibuat produk dalam bentuk minuman. Penelitian ini bertujuan untuk mereformulasi corigens saporis dan odoris dalam sediaan instan collagen rousselot's dengan formula yang tepat. Metode yang digunakan dengan mereformulasi corigens saporis dan odoris dari perisa dan minyak atsiri, pemanis Stevia rebaudiana (Ber.) dan sukralosa dengan konsentrasi berurutan 1\%, 2\%, 3\%, 4\%, 5\%, 6\%, 7\%, 8\%, 9\% 10\%. Dan massa pengikat xanthan gum 0,05\%, 0,10\%, 0,15\% dalam bentuk granul untuk $200 \mathrm{ml}$ penyajian. Sediaan instan collagen rousselot's di uji organoleptik (penampilan, bau, rasa dan tekstur) dari 20 responden dianalisis dengan statistika ANOVA satu arah. Hasil penelitian dapat disimpulkan bahwa konsentrasi xanthan gum 0,05\% berpengaruh terhadap sifat fisik granul, semakin rendah konsentrasi xanthan gum, semakin rendah nilai kadar air $\mathrm{Fl}=1,67 \%, \mathrm{~F} 2=2,3 \% \mathrm{FII}=3 \%$, dan waktu alir $\mathrm{Fl}=0,98 \mathrm{~s}, \mathrm{FIl}=1,09 \mathrm{~s}, \mathrm{FII}=1,68 \mathrm{~s}$, Dari ke-3 formula yang dibuat semuanya dapat menutupi bau dan rasa yang kurang enak ketika dikonsumsi dan formula dengan kriteria yang baik berdasarkan Uji organoleptik yaitu formula I dengan nilai uji penampilan $75 \%$, bau $60 \%$, rasa $45 \%$ dan tekstur $65 \%$.
\end{abstract}

Kata kunci: Corigens, Peptan, Stevia rebaudiana (Ber.)

\section{Pendahuluan}

Imobilisasi, intoleransi aktivitas, dan sindrom disuse sering terjadi pada penduduk lanjut usia. Imobilisasi di definisikan secara luas sebagai tingkat aktivitas atau kegiatan yang kurang dari mobilisasi normal biasanya ${ }^{(1)}$. Dampak fisiologis dari imobilisasi dan kepasifan adalah dengan terjadinya peningkatan katabolisme protein sehingga dapat menyebabkan penurunan kekuatan otot. Selain itu penduduk lanjut usia juga sangat rentan terhadap konsekuensi fisiologis dan psikologis dari imobilitas ${ }^{(2)}$. 
Secara fisiologis, tubuh akan bereaksi terhadap imobilitas dengan segala perubahan perubahan yang mirip dengan proses penuaan, oleh karena itu akan semakin memperberat efek penuaan. Padahal, kebanyakan efek proses penuaan seringkali dapat segera teratasi bila tubuh dijaga tetap sehat dan aktif(3). Dari 10 hingga 15\% kekuatan otot dapat menghilang setiap minggunya jika otot beristirahat sepenuhnya, dan sebanyak $5,5 \%$ dapat hilang setiap hari pada kondisi istirahat dan imobilitas sepenuhnya ${ }^{(4)}$.

Lingkungan internal, atau kompetensi klien adalah faktor penentu mobilitas yang paling penting ketika derajat imobilitas yang lebih rendah terjadi. Karena kompetensi lansia menurun, ia bergantung lebih besar pada lingkungan eksternal untuk mempertahankan mobilitas. Sebagai contoh, jika seorang pasien lansia hemiplegi dengan kelemahan otot berat dianjurkan untuk menggunakan kursi roda listrik, sumber-sumber dari lingkungan eksternal membantu meniadakan keterbatasan lingkungan internal. Jadi, penjelasan secara singkat adalah lansia yang mengalami gangguan imobilisasi fisik seharusnya melakukan latihan aktif agar tidak terjadi penurunan kekuatan otot. Namun pada kenyataannya banyak lansia yang masih tergantung dengan lingkungan eksternal, sehingga kompetensinya menurun(5).

Banyak penduduk lanjut usia yang mempunyai karakteristik seperti adanya tanda penurunan pada regeneratif sendi. Penurunan tersebut yaitu penurunan fleksibilitas sendi pada usia 30-70 tahun yang bisa mencapai 40-50\%, sehingga dianjurkan banyak melakukan aktivitas fisik seperti berolahraga dan mengkonsumsi nutrisi persendian. Salah satu nutrisi yang dapat memberikan manfaat untuk kesehatan sendi ialah collagen ${ }^{(6)}$. Collagen dan elastin (Jaringan penghubung) Pendukung utama kulit, tendon, tulang, kartilago dan jaringan merupakan ciri dari kolagen. Jaringan kolagen adalah salah satu contoh terjadinya penurunan mobilitas jaringan tubuh. Struktur kolagen mengalami penurunan seperti turunya flexibilitas pada lansia sehingga menimbulkan dampak berupa nyeri, penurunan kekuatan otot, kemampuan dari duduk ke berdiri, jongkok dan berjalan,serta terjadi hambatan dalam melakukan aktivitas setiap hari(6). Collagen yang akan dipakai dalam penelitian ini adalah collagen rousselot's tipe I dengan brand Peptan $\AA$.

Collagen rousselot's ini terdapat tipe I dan tipe II, untuk Peptan® tipe I merupakan collagen peptida dengan jenis nutrisi sama yang dapat ditemukan pada nutrisi tulang/kulit pada umumnya. Dalam bentuk terhidrolisis mampu membuatnya mudah dicerna yang lain pada peptan tipe I ini merupakan produk alami dengan kemurnian tinggi yang mengandung lebih dari $97 \%$ protein (berdasarkan berat kering). Sedangkan untuk peptan tipe II (Peptan $\AA \mathrm{IIm}$ ) merupakan matriks collagen terhidrolisis yang berasal dari alam yang mempunyai kandungan GAG yaitu collagen terhidrolisis dalam bentuk peptida bioaktif dan glikosaminolaktan. Dengan komposisi unik inilah peptan tipe II mengandung bahan matriks yang sama yang dapat ditemukan ditulang rawan manusia serta dapat mendukung banyak manfaat kesehatan sendi dengan dosis harian yang relatif rendah (Vostra Cosa, 2019). 
Collagen dengan brand peptan® mempunyai kadar asam amino tinggi diantaranya glisin, hidroksiprolin, alanin dan arginin yang dapat memberikan manfaat gizi yang tidak ditemukan dalam sumber-sumber protein lainnya, disamping fungsi collagen yang dapat memperbaiki fungsi persendian collagen dengan brand peptan ${ }^{\circledR}$ terdapat kekurangan yaitu mempunyai bau dan rasa yang tidak enak untuk dikonsumsi(16). Dalam menentukan solusi dari permasalahan Collagen dengan brand peptan ${ }^{\circledR}$ yang mempunyai bau dan rasa tidak enak ketika dikonsumsi maka penelitian ini bertujuan untuk mengetahui pengaruh kombinasi corigens saporis dari ekstrak serbuk Stevia rebaudiana (Ber.), sukralosa, minyak atsiri dari jahe (Zingiber officinale Rosc), sereh (Cymbopogon nardus), daun peppermint (Mentha piperita), daun jeruk purut (Citrus hystrix DC.) dan corigens odoris dari perisa lemon dan green tea serta bahan pengikat xanthan gum dengan mendapatkan reformulasi corigens saporis dan odoris yang tepat.

\section{Metode}

\section{Alat}

Peralatan yang digunakan yaitu Neraca Analitik (ADAM SCIENTIFIC) Spatula, Gelas ukur (IWAKI), Beaker glass (IWAKI), Corong (HERMA), Pipet tetes, Cawan porselen, Kaca arloji, Kertas saring, Ayakan Mesh 12 dan Mesh 16, Alat uji kadar air (MOISTURE BALANCE), Alat uji waktu alir (FLOW TESTER), Oven, Desikator.

\section{Bahan}

Bahan yang digunakan yaitu Collagen rousselot's tipe 1 dengan brand Peptan $\AA$ dari PT. DARLING Ingredients, Ekstrak serbuk tanaman stevia rebaudiana (Ber) dari PT.GL STEVIA, Minyak atsiri dari Daun Sereh (Cymbopogon nardus), Jahe (Zingiber officinale Rosc), Jeruk Purut (Citrus hystrix DC.) dari PT. Sinkona Indonesia Lestari dan Minyak atsiri Peppermint (Mentha piperita) dari Anhui Province Yifan Spice Co., Ltd. Perisa lemon, Perisa green tea dan Air/water.

\section{Prosedur}

1. Formulasi Sediaan Granul Instan

Granul instan dibuat dengan cara metode granulasi basah. Bahan dalam formula ditimbang sesuai yang dibutuhkan campur dan aduk sampai homogen. Terbentuknya massa yang kempal setelah semua bahan tercampurkan secara homogen yang kemudian ditambahkan air sedikit demi sedikit hingga terbentuk massa basah. Massa basah kemudian diayak menggunakan ayakan mesh 12 hingga terbentuk granul. Granul yang diperoleh dikeringkan dalam oven pada suhu 40-500C selama \pm 2 jam sampai granul kering. Granul kering diayak menggunakan ayakan mesh 16 dan tambahkan flavour aduk rata sampai tercampur homogen. Kemudian granul yang terbentuk dilakukan pengujian fisik granul(7). 


\section{Uji Fisik Granul}

a. Kadar air

Pengujian ini dilakukan menggunakan alat keseimbangan kelembapan (moisture balance). seluruh granul yang sudah dilakukan pemanasan dengan oven dimasukan kedalam alat moisture balance sebanyak $10 \mathrm{~g}$. Kemudian granul diratakan, dan data yang dihasilkan berupa kadar air yang terkandung dalam granul. Syarat granul untuk kadar air 2-5\%.

b. Susut Pengeringan

Seluruh granul basah yang sudah diayak ditimbang seksama dalam cawan yang telah diketahui bobotnya kemudian dikeringkan pada suhu $40^{\circ} \mathrm{C}$, Granul yang mencapai kelembaban 2-4\% ditentukan berdasarkan waktu. Setelah itu dilakukan replikasi.

c. Sifat Granul Instan

Sifat alir adalah pengujian dengan menggunakan alat flow tester, dan dinilai dari waktu yang dibutuhkan sejumlah granul untuk mengalir dalam alat tersebut. sifat alir ini dapat memperbaiki suatu granul dengan menilai efektivitas dari bahan pelicin.

\section{Uji Evaluasi Sediaan}

a. Waktu Larut dalam Air

Timbang sampel sebanyak 5 gram kemudian larutkan sampel dalam $50 \mathrm{ml}$ air diaduk hingga homogen dicatat berapa lama waktu sampel dapat terlarut sempurna dalam air.

b. Bagian tidak larut dalam Air

Timbang 5 gram sampel masukan kedalam beaker glass $500 \mathrm{ml}$, tambahkan 200 $\mathrm{ml}$ air kedalamnya aduk hingga larut. Setelah itu tuang kedalam kertas saring yang telah dikeringkan dalam oven dan diketahui beratnya. Beaker glass dan kertas saring dibilas dengan aquadest hingga diperoleh residu pada kertas saring. Kertas saring dikeringkan dalam oven pada suhu $105^{\circ} \mathrm{C}$ selama 2 jam, dinginkan dalam desikator dan timbang.

c. Uji Organioleptik

Pengujian yang didasarkan pada proses penginderaan merupakan pengujian organoleptik dengan menggunakan bagian organ tubuh yang mempunyai peran penginderaan meliputi mata, indera pencium (hidung), indera pengecap (lidah) yang dilakukan terhadap 20 orang panelis. 


\section{Hasil}

a. Determinasi Tanaman

Stevia (Stevia rebaudiana (Ber) ) yang digunakan dalam penelitian ini diambil dari Kebun percobaan Manoko, Lembang Bandung, Kebun dibawah Balitro Bogor, Kabupaten Bandung, Provinsi Jawa Barat. Dari hasil determinasi tersebut menunjukkan bahwa sampel merupakan tanaman Stevia (Stevia rebaudiana (Ber)) dengan suku compositae.

b. Ekstraksi

Ekstraksi dilakukan dengan penyerapan resin yang kemudian di daur ulang dengan alkohol dan didekolorasi pada konsentrasi membran dan efek tunggal dengan hasil akhir kristalisasi yang menghasilkan bentuk serbuk putih.

c. Uji Kemurnian Minyak Atsiri

Hasil uji kemurnian minyak atsiri diperoleh berdasarkan perbandingan pengujian antara yang telah dilakukan oleh PT. Sinkona Indonesia Lestari untuk Minyak atsiri sereh (Cymbopogon nardus), Minyak atsiri jahe (Zingiber officinale Rosc), Minyak atsiri jeruk purut(Citrus hystrix DC.) dan Anhui Province Yifan Spice Co.,Ltd untuk Minyak atsiri daun peppermint (Mentha piperita) dengan hasil yang telah diujikan terhadap minyak atsiri tersebut.

d. Formulasi corigens saporis dan odoris

Sediaan diformulasikan menjadi minuman bernutrisi dengan kombinasi penambahan stevia sebagai pemanis alami dan sukralosa sebagai pemanis buatan sebanyak $5 \%$ yang kemudian ditambahkan bahan pengikat yaitu xanthan gum sebanyak $0,05 \%$ pada masing-masing formula. Dengan penambahan pengaroma dan perisa yang berbeda konsentrasi dari masing-masing formula yang dibuat yaitu untuk Formula 1 minyak atsiri sereh (Cymbopogon nardus), minyak atsiri jahe (Zingiber officinale Rosc) sebanyak $0,05 \mathrm{~g} / \mathrm{ml}$ dengan perisa lemon sebanyak 2 $\mathrm{g} / \mathrm{ml}$. Formula 2 terdiri dari minyak peppermint (Mentha piperita) sebanyak $0,05 \mathrm{~g} / \mathrm{ml}$ dengan penambahan perisa lemon sebanyak $2 \mathrm{~g} / \mathrm{ml}$ dan untuk Formula 3 yaitu minyak atsiri jeruk purut (citrus hystrix DC) dan minyak atsiri peppermint (Mentha piperita) sebanyak $0,05 \mathrm{~g} / \mathrm{ml}$ dengan penambahan perisa green tea sebanyak 2 $\mathrm{g} / \mathrm{ml}$.

\section{Pembahasan}

Sediaan diformulasikan menjadi minuman bernutrisi dengan kombinasi penambahan stevia sebagai pemanis alami dan sukralosa sebagai pemanis buatan sebanyak $5 \%$ yang kemudian ditambahkan bahan pengikat yaitu xanthan gum sebanyak 0,05\% pada masing-masing formula. Dengan penambahan pengaroma dan perisa yang berbeda konsentrasi dari masing-masing formula yang dibuat yaitu untuk Formula 1 minyak atsiri sereh (Cymbopogon nardus), minyak atsiri jahe (Zingiber officinale Rosc) sebanyak 
$0,05 \mathrm{~g} / \mathrm{ml}$ dengan perisa lemon sebanyak $2 \mathrm{~g} / \mathrm{ml}$. Formula 2 terdiri dari minyak peppermint (Mentha piperita) sebanyak $0,05 \mathrm{~g} / \mathrm{ml}$ dengan penambahan perisa lemon sebanyak $2 \mathrm{~g} / \mathrm{ml}$ dan untuk Formula 3 yaitu minyak atsiri jeruk purut (citrus hystrix DC) dan minyak atsiri peppermint (Mentha piperita) sebanyak $0,05 \mathrm{~g} / \mathrm{ml}$ dengan penambahan perisa green tea sebanyak $2 \mathrm{~g} / \mathrm{ml}$.

Tabel 1. Hasil Uji Fisik Granul

\begin{tabular}{lccc}
\hline \multicolumn{1}{c}{ Uji Fisik Granul } & $\mathrm{F} 1$ & $\mathrm{~F} 2$ & $\mathrm{~F} 3$ \\
\hline Uji Kadar air & $1,67 \pm 0,57$ & $2,33 \pm 0,57$ & $3 \pm 0$ \\
Uji Susut pengeringan & $2,33 \pm 0,57$ & $3,33 \pm 0,57$ & $3,33 \pm 0,57$ \\
Uji sifat alir (detik) & $0,98 \pm 0,24$ & $1,09 \pm 0,08$ & $1,68 \pm 0,90$ \\
\hline
\end{tabular}

Keterangan : Hasil rata-rata \pm standar deviasi dari 4 kali pengukuran

Formula I : : Xanthan gum 0,05\%

Formula II : : Xanthan gum $0,10 \%$

Formula III : : Xanthan gum $0,15 \%$

Sumber : (Dokumen Pribadi)

Hasil waktu larut dalam air nilai waktu larut air yang didapatkan dari formula 1 sampai 3 pada Tabel 2 berkisar antara 39,52 - 48,44 detik. Pada Tabel 2 Waktu larut air terendah yaitu pada formula 1 dan nilai waktu larut air tertinggi terdapat pada formula 3. Menurut Fennema (1985), peningkatan kadar air dalam bahan pangan akan membentuk ikatan yang mengakibatkan terbentuknya gumpalan dalam memecahkan ikatan antar partikel yang membutuhkan waktu yang lebih lama dan salah satu faktor yang mempengaruhi waktu larut adalah kadar air bahan, semakin tinggi kadar air dalam minuman serbuk instan maka semakin lama waktu yang dibutuhkan untuk larut. Bagian tidak larut air yang diperoleh berkisar antara 0,5781-5873 detik, dengan bagian tidak larut air tertinggi pada minuman kolagen dengan bahan pengikat $0,10 \%$ pada formula 2 dan 3 dengan bahan pengikat xanthan gum $0,15 \%$ dan bagian tidak larut terendah pada minuman collagen terdapat pada Formula 1 dengan bahan pengikat xanthan gum $0,05 \%$ seperti pada keterangan Tabel 2. Hal ini disebabkan karena Formula 2 dan 3 konsentrasi xanthan gum terlalu tinggi dengan sifat viskositas tinggi pada xanthan gum.

Hasil waktu larut dalam air nilai waktu larut air yang didapatkan dari formula 1 sampai 3 pada Tabel 2 berkisar antara 39,52 - 48,44 detik. Pada Tabel 2 Waktu larut air 
terendah yaitu pada formula 1 dan nilai waktu larut air tertinggi terdapat pada formula 3. Menurut Fennema (1985), peningkatan kadar air dalam bahan pangan akan membentuk ikatan yang mengakibatkan terbentuknya gumpalan dalam memecahkan ikatan antar partikel yang membutuhkan waktu yang lebih lama dan salah satu factor yang mempengaruhi waktu larut adalah kadar air bahan, semakin tinggi kadar air dalam minuman serbuk instan maka semakin lama waktu yang dibutuhkan untuk larut. Bagian tidak larut air yang diperoleh berkisar antara 0,5781-5873 detik, dengan bagian tidak larut air tertinggi pada minuman kolagen dengan bahan pengikat $0,10 \%$ pada formula 2 dan 3 dengan bahan pengikat xanthan gum $0,15 \%$ dan bagian tidak larut terendah pada minuman collagen terdapat pada Formula 1 dengan bahan pengikat xanthan gum $0,05 \%$ seperti pada keterangan Tabel 2. Hal ini disebabkan karena Formula 2 dan 3 konsentrasi xanthan gum terlalu tinggi dengan sifat viskositas tinggi pada xanthan gum.

Tabel 2. Hasil Uji Sediaan

\begin{tabular}{lccc}
\hline Uji Fisik granul & F1 & F2 & F3 \\
\hline Uji waktu larut air & $1,67 \pm 0,57$ & $2,33 \pm 0,57$ & $3 \pm 0$ \\
Uji bagian tidak larut air & $2,33 \pm 0,57$ & $3,33 \pm 0,57$ & $3,33 \pm 0,57$ \\
\hline
\end{tabular}

Keterangan : Hasil rata-rata \pm standar deviasi dari 4 kali pengukuran

Formula I : Xanthan gum $0,05 \%$

Formula II : : Xanthan gum $0,10 \%$

Formula III : : Xanthan gum $0,15 \%$

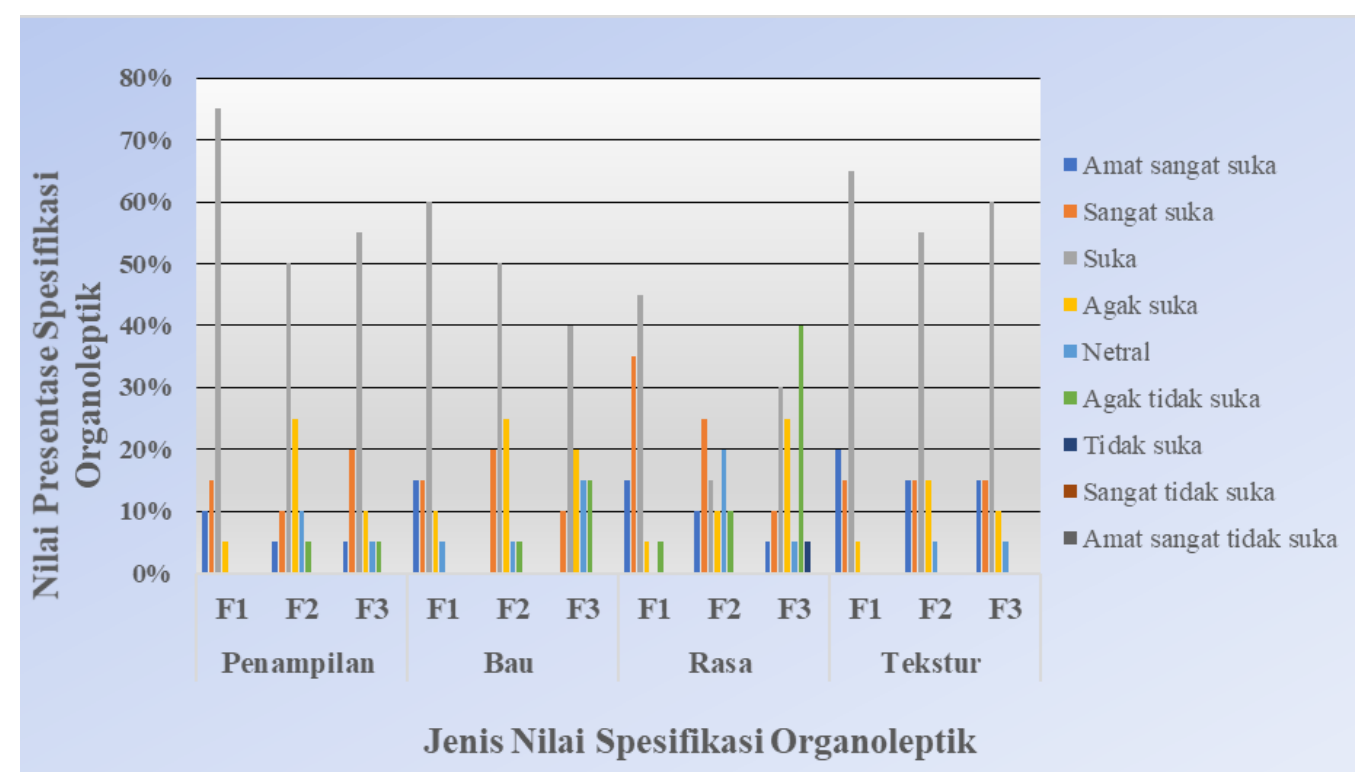

Gambar 1. Hasil Uji Organoleptik (Penampilan, Bau, Rasa, dan Tekstur)

Sumber : (Dokumen Pribadi) 
Pengujian organoleptik dilakukan berdasarkan uji hedonik atau uji kesukaan pada 20 responden terhadap pengujian penampilan, bau, rasa dan tekstur pada 9 paramater penilaian seperti yang terdapat pada Gambar 1 yaitu : (1) amat sangat suka; (2) sangat suka; (3) suka; (4) agak suka; (5) netral; (6) agak tidak suka; (7) tidak suka; (8) sangat tidak suka; (9) amat sangat tidak suka. Pada uji organoleptik dari ke-3 masingmasing Formula berdasarkan penampilan didapatkan bahwa rentang presentase(\%) dengan perolehan tertinggi nilai suka terdapat pada Formula 1 sebanyak $75 \%$ tanpa disertai hal ini dikarenakan minyak atsiri yang digunakan tidak meninggalkan kesan keruh terhadap penampilan formula minuman, dan hasil uji kemurniannya pun sesuai dengan standar. Berdasarkan bau didapatkan bahwa perolehan nilai parameter suka (6) tertinggi diperoleh pada Formula 1 dengan nilai $60 \%$, dan nilai terendah diperoleh Formula 3. Hal ini disebabkan karena pada Formula 3 tingginya kandungan sitronelal pada daun jeruk purut (Citrus hystrix DC) yaitu sebanyak $(48,2 \%)$ yang mempengaruhi penilaian bau dari 20 responden terhadap formula yang dibuat.

Organoleptik rasa berdasarkan nilai parameter Tidak suka (7) dengan presentase (\%) terbesar terdapat pada formula 3 sebanyak $5 \%$ dari 20 reponden sedangkan untuk Formula 1 dan 2 sebanyak $0 \%$ menunjukkan nilai parameter tidak suka dengan adanya rasa getir / pahit pada minuman. Hal ini disebabkan karena pada Formula 3 terdapat minyak atsiri jeruk purut (Citrus hystrix DC) memiliki kandungan Limonoid dalam daun dan buah jeruk purut sehingga mengakibatkan rasa getir atau pahit (Devy, Yulianti dan Andrini, 2010). Berdasarkan tekstur didapatkan hasil bahwa nilai parameter netral (5) dengan perolehan presentase paling kecil sebanyak $0 \%$ hanya terdapat pada formula 1 , formula 2 dan 3 memiliki nilai presentase yang sama yaitu sebanyak $5 \%$. Hal ini dikarenakan tekstur granul pada formula 2 dan 3 kurang merata dan menyebabkan reponden kurang menyukainya.

\section{Kesimpulan}

Bahwa pengaruh kombinasi corigens dari ekstrak serbuk daun stevia, sukralosa dan penambahan rasa dari berbagai minyak atsiri mampu menutupi bau dan rasa dari zat aktif (peptan).

Formula dengan kriteria yang baik berdasarkan reformulasi corigens Stevia rebaudiana, sebagai pemanis, minyak atsiri jahe dan sereh sebagai perisa serta Uji organoleptik yaitu formula 1 dengan nilai uji kenampakan $75 \%$, bau $60 \%$, rasa $45 \%$ dan tekstur $65 \%$.

\section{Daftar Pustaka}

Agoes G. Teknologi Bahan Alam (Serial Farmasi Industri-2). 2020.

Azis YM, Muhyiddin MF, Harismah K. Formulasi dan Uji Sifat Fisik Kimia Sirup Stevia Aroma Cengkeh. URECOL; 2017 Sep 7:201-4. 
Azni IN, Amelia JR. Karakteristik kimia minuman okra dengan penambahan daun stevia dan ekstrak jahe. Jurnal Agroindustri Halal. 2019 Apr 30;5(1):001-8.

Angria M. Pembuatan minuman instan pegagan (Centella asiatica) dengan citarasa cassia vera. Skripsi.(tidak dipubliksikan) Fakultas Teknologi Pertanian. Universitas Andalas Padang. 2011.

Azzahra P. Pengaruh Suhu dan Volume Air pada Destilasi Penyulingan Minyak Atsiri Tipe Uap dan Air pada Tanaman Sirih Hijau (Piper betle L.). 2018.

Cui SW. Polysaccharide gums from agricultural products: Processing, structures and functionality. CRC Press; 2000 Oct 26.

Devy NF, Yulianti Y, Andrini A. Kandungan Flavonoid dan Limonoid pada Berbagai Fase Pertumbuhan Tanaman Jeruk Kalamondin (Citrus mitis Blanco) dan Purut (Citrus hystrix Dc.). Jurnal Hortikultura. 2010 Mar 3;20(1).

Dinianti SR, Rihiantoro T, Astuti T. Senam Lansia dan Kekambuhan Nyeri Sendi pada Lansia penderita Arthritis. Jurnal Ilmiah Keperawatan Sai Betik. 2017 Jan 27;9(2):246-51.

Durotulailah, L. Formulasi sediaan tablet hisap ekstrak pegagan (centella asiatica (Linn) Urban) dengan stevia (stevia rebaudiana) sebagai pemanis. Skripsi. Universitas Jenderal Achmad Yani. Bandung. 2010.

Fenema, OW. Principle of Food Science, Food Chemistry. Edisi Kedua. New York; Mercel Dekker Inc. 1985.

Gupta S, Kalra S, Bharihoke V, Dhurandar D. Sucralose induced pancreatic toxicity in albino rats: Histomorphological evidence. J. Morphol. Sci. 2014;31(2):123-7.

Guenther. Minyak Atsiri Jilid I. 1987. Terjemahan Kateren dan Mulyono J.Jakarta. UI Press. 1990

Handoko, K. Diagnosis dan Penatalaksanaan Osteoartritis. 2005.

Hartomo AJ, Widiatmoko MC. Emulsi dan Pangan Instant Ber-Lesitin. Yogyakarta .Penerbit Andi; 1993.

Hidayat S, Hutapea. Inventaris Tanaman Obat Indonesia. Jakarta: Departemen Kesehatan RI; 1991.

Iscan G, Kïrìmer N, Kurkcuoglu M, Baser HC, Demirci F. Antimicrobial screening of Mentha piperita essential oils. Journal of agricultural and food chemistry. 2002 Jul 3;50(14):3943-6.

Kementrian Kesehatan RI. Analisis Lansia di Indonesia. Jakarta. Pusat Data dan Informasi Kementrian Kesehatan RI. 2017. 
Lemus-Mondaca R, Vega-Gálvez A, Zura-Bravo L, Ah-Hen K. Stevia rebaudiana Bertoni, source of a high-potency natural sweetener: A comprehensive review on the biochemical, nutritional and functional aspects. Food chemistry. 2012 Jun 1;132(3):1121-32.

Lachman L, Lieberman HA, Kanig JL. Teori dan praktek farmasi industri. Edisi III. Jilid 2. Jakarta; UI Press; 1994.

Mucciarelli M, Scannerini S, Bertea C, Maffei M. In vitro and in vivo peppermint (Mentha piperita) growth promotion by nonmycorrhizal fungal colonization. New Phytologist. 2003 Jun;158(3):579-91.

Mulyadi MD, Astuti IY, Dhiani BA. Formulasi Granul Instan Jus Kelopak Bunga Rosela (Hibiscus Sabdariffa L) Dengan Variasi Konsentrasi Povidon Sebagai Bahan Pengikat Serta Kontrol Kualitasnya. PHARMACY: Jurnal Farmasi Indonesia (Pharmaceutical Journal of Indonesia). 2016 Oct 26;8(03).

Peraturan Kepala Badan Pengawas Obat dan Makanan RI. Batas Maksimum Penggunaan Bahan Tambahan Pangan Pemanis. Jakarta; Kepala Badan Pengawas Obat dan Makanan; 2014.

Peraturan Kepala Badan Pengawas Obat dan Makanan RI. 2013. Batas Maksimum Penggunaan Bahan Tambahan Pangan Pengawet. Jakarta; BPOM; 2013.

Peraturan Menteri Kesehatan RI. Angka Kecukupan Gizi Orang Indonesia. Jakarta; PERMENKES; 2013.

Peraturan Menteri Kesehatan RI. Analisis Lansia di Indonesia. Jakarta; Pusat data dan Informasi Kementrian Kesehatan Rl; 2017.

Peraturan Badan POM RI. Monografi Ekstrak Tumbuhan Obat Indonesia. Vol 1. Direktorat Standarisasi Obat Tradisional, Kosmetik dan Produk Komplemen. Jakarta; BPOM; 2010.

Plantamor. Tanaman Rempah Planamor [diunduh 05 Januari 2020]. Tersedia dari : http://www.plantamor.com/katalog/tanaman-rempah/jahe i504.

Prasetya M, Maghfoer MD, Santoso M. Pengaruh macam dan kombinasi bahan organik terhadap pertumbuhan dan hasil tanaman Stevia (Stevia rebaudiana (Ber).). Jurnal Produksi Tanaman. 2014 Jul 10;2(6).

Raini M, Isnawati A. Kajian: khasiat dan keamanan stevia sebagai pemanis pengganti gula. Media Penelitian dan Pengembangan Kesehatan. 2011;21(4) : 145156.

Ramadian DA. 1 Gambaran Fungsi Kognitif Pada Lansia Di Tiga Yayasan Manula Di Kecamatan Kawangkoan. e-CliniC. 2013;1(1).

Rianto, J., Handoko, W. dan Novianry, V. Pengaruh Konsumsi Produk yang Mengandung Pemanis Buatan Rendah Kalori terhadap Kadar Glukosa Darah Puasa dan Gangguan Toleransi Glukosa pada Tikus Galur Wistar. Jurnal Kesehatan Khatulistiwa. 4(1). :557-567 
Rifkowaty, Martanto. Minuman Fungsional Serbuk Instan Jahe ( Zingiber officinale Rosc ) Dengan Variasi Penambahan Ekstrak Bawang Mekah ( Eleutherine americana Merr ) Sebagai Pewarna Alami. Lampung: Jurnal Teknik Pertanian Lampung; 2018 4(4). : 315-324.

Rousselot, D. O. Sehat sendi dan tulang Penuaan dan gaya hidup permintaan untuk nutrisi kesehatan sendi dan tulang. Netherlands; peptan; 2011.

Rukmana, R. Budi Daya Stevia. $5^{\text {nd }}$ ed. Yogyakarta; Kanisius; 2013.

Rowe, R.,Sheskey dan Quinn, M. Handbook of Pharmaceutical Excipients.Sixth Edition. London : Pharmaceutical Press; 2009.

Sella, D. A., Sahruddin dan Ibrahim, K. Hubungan Intensitas Sholat, Aktivitas Olahraga dan Riwayat Kebiasaan Mandi Malam dengan Penyakit Osteoartritis Pada Lansia di Panti Sosial Tresna Werdha Minaula Kota Kendari Tahun 2017. Jurnal Mahasiswa Kesehatan Masyarakat. 2017; 2(6) : 1-9.

Setiawan A, Kunarto B, Sani EY. Ekstraksi Daun Peppermint (Mentha piperita L.) Menggunakan Metode Microwave Assisted Extraction Terhadap Total Fenolik, Tanin, Flavonoid dan Aktivitas Antioksidan. 2019; 50 : 1-9.

Siregar C. Proses Validasi dan Manufaktur Sediaan Tablet. Bandung: FMIPA, ITB; 1992.

Sidik RF. Pembelajaran ilmu pengetahuan alam tematik berbasis tanaman obat keluarga (TOGA). Jurnal Pena Sains. 2014 Apr;1(1). : 67-74.

Sulaswatty A. Minyak Serai Wangi Dan Produk Turunannya. Jakarta: LIPI Press; 2019.

Syarifah T. Ekstraksi Minyak Atsiri Dari Batang, Daun dan Kulit Jeruk Purut (Citrus hystrix DC) Dengan Metode Solvent-Free Microwave Extraction. Surabaya: Institut Teknologi Sepuluh Nopember; 2017. Tetti M. Ekstraksi, pemisahan senyawa, dan identifikasi senyawa aktif. Jurnal Kesehatan. 2014 Sep $11 ; 7(2): 361-367$.

Voight, Rudolf. Buku Pelajaran Teknologi Farmasi Edisi ke-5. Yogyakarta: Gadjah Mada University Press; 1994.

Widiyastuti Y, Widyastuti R, Solikhah IM, Subositi D. Karakterisasi Morfologi dan Profil Kromatogram Minyak Atsiri 3 Jenis Mentha Koleksi Balai Besar Penelitian dan Pengembangan Tanaman Obat dan Obat Tradisional. Semarang: Seminar Nasional Fakultas Pertanian UNS; 2018 2(1). : 317-326. 